\title{
Inclusion of health care for people with disabilities in Brazilian undergraduate medical education
}

\author{
Inclusão do cuidado com a saúde das pessoas com deficiência nos currículos de medicina do Brasil
}

\author{
Reginaldo Antônio de Oliveira Freitas Júnior ${ }^{1,2}$ (D) $\mid$ reginaldo@isd.org.br

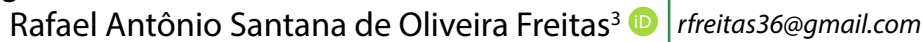 \\ Marcelo Pacheco Carvalho' (1) marcelo.carvalho@isd.org.br \\ Samantha Santos de Albuquerque Maranhão' (D) samantha.maranhao@isd.org.br \\ Lilian Lira Lisboa ${ }^{1,2}$ (D) lilian.lisboa@isd.org.br \\ George Dantas de Azevedo² (D) georgedantas.faimer@gmail.com
}

\begin{abstract}
Introduction: In Brazil, official data estimate there are 45.6 million people with some type of disability and legislation establishes that medical schools should prepare future professionals for the essential care for people with disabilities (PWD). Health disparities faced by PWD are due, among other factors, to inadequate access to healthcare and poor training of professionals to deal with these situations.

Objective: To identify the presence of aspects related to PWD healthcare in the curricula of medical courses in Brazil.

Method: A documentary analysis of curricula and syllabuses was performed and included research in websites of 328 medical courses (42\% public and $58 \%$ private) authorized by the Brazilian Ministry of Education. The Brazilian National Curricular Guidelines (NCG) were adopted as a theoretical framework (Brazil, 2014). The classification considered was: Class I - minimum attendance of the pedagogical project to the recommendations on care for PWD, due to the strict transcription of the NCG text and Class II - inclusion in the syllabus and programmatic content of the reference curricular components to the development of specifically related clinical skills to the health care of the PWD, including communication, clinical examination skills and ethical aspects.
\end{abstract}

Results: Documents from 171 courses were available for analysis and the inclusion of aspects related to PWD healthcare was identified in 89 courses $(52 \%)$. This inclusion was more prevalent in public courses $(n=56 ; 62,9 \%)$ than in private ones. The inclusion of the teaching of the Brazilian Sign Language (Libras) was observed In 50 courses (29.2\%). The curricular contents were predominantly focused on the Class I ( $n=80 ; 89,9 \%)$ with an absolute lack of description of the procedural strategies to promote the development of clinical competencies related to PWD care.

Conclusion: Our study reinforces the need to improve this approach in medical school curricula since providers can play an essential role in mitigating health disparities faced by PWD through competent care. In the Brazilian context, our data point out to a dramatic situation consistent with the invisibility of PWD issues; a need for the development and implementation of PWD-specific educational curricula.

Keywords: Disabled Persons; Medical Education; Curriculum; Medical Schools.

\section{RESUMO}

Introdução: No Brasil, estima-se que haja 45,6 milhões de pessoas com alguma deficiência. As disparidades de saúde enfrentadas pelas pessoas com deficiência (PCD) decorrem, entre outros fatores, do acesso inadequado aos cuidados de saúde e da formação deficiente dos profissionais para lidar com essas situações.

Objetivo: Este estudo teve como objetivo identificar a presença de aspectos relacionados com a atenção à saúde das PCD nos currículos dos cursos de Medicina do Brasil.

Método: Foi realizada análise documental dos projetos pedagógicos dos cursos, dos currículos, das ementas de componentes curriculares e dos conteúdos programáticos, incluindo pesquisas em sites de 328 cursos de Medicina (42\% públicos e 58\% privados) autorizados pelo Ministério da Educação. As Diretrizes Curriculares Nacionais (DCN) do Curso de Graduação em Medicina foram adotadas como referencial teórico. A classificação considerada foi: classe I - atendimento mínimo do projeto pedagógico às recomendações sobre o cuidado para PCD, pela estrita transcrição do texto das DCN, e classe II - inclusão nas ementas e nos conteúdos programáticos dos componentes curriculares de atividades voltadas ao desenvolvimento de competências clínicas especificamente relacionadas ao cuidado destinado à saúde das PCD, incluindo comunicação, exame clínico e aspectos éticos. Resultado: Documentos de 171 cursos estavam disponíveis para análise adequada. Desse total, em 89 cursos (52\%) foi identificada a inclusão de aspectos relacionados ao cuidado com PCD, sendo mais prevalente nos cursos públicos ( $n=56 ; 62,9 \%)$. Em 50 ( $29,2 \%)$ cursos, observou-se a inclusão do ensino da Língua Brasileira de Sinais (Libras). Os conteúdos curriculares identificados foram predominantemente focados na classe I ( $n=80 ; 89,9 \%$ ), com absoluta falta de descrição das estratégias processuais para promover o desenvolvimento de competências clínicas relacionadas ao cuidado para PCD.

Conclusão: No contexto brasileiro, os dados apontam para uma situação dramática no que se refere à invisibilidade das questões relativas às PCD na formação médica e para a necessidade de desenvolvimento e implementação de estratégias educacionais especificamente voltadas para o cuidado com as $P C D$ nos currículos médicos. O estudo reforça o papel essencial do cuidado competente destinado à saúde das PCD como estratégia que visa à mitigação das iniquidades de saúde enfrentadas por essas pessoas.

Palavras-chave: Pessoas com Deficiência; Educação Médica; Currículo; Escolas Médicas.

${ }^{1}$ Instituto de Ensino e Pesquisa Alberto Santos Dumont, Macaíba, Rio Grande do Norte, Brazil.

${ }^{2}$ Universidade Federal do Rio Grande do Norte, Natal, Rio Grande do Norte, Brazil.

${ }^{3}$ Faculdade de Ciências Médicas da Santa Casa de São Paulo, São Paulo, São Paulo, Brazil.

Chief Editor: Rosiane Viana Zuza Diniz. Associate Editor: Kristopherson Lustosa Augusto.

Received on 03/03/21; Accepted on 06/07/21. | Evaluated by double blind review process. 


\section{INTRODUCTION}

The World Health Organization estimates that $15 \%$ of the world's population has disabilities ${ }^{1}$. In Brazil, according to the 2010 IBGE Census, 45.6 million people declared to have some type of disability, representing $23.9 \%$ of the population living in the country ${ }^{2}$. These numbers express the importance that care to the health needs of this specific population must assume in the context of the effectiveness of health systems.

The National Plan for the Rights of Persons with Disabilities - Living Without Limits ${ }^{3}$ emphasizes Brazil's commitment to the prerogatives of the Convention on the Rights of Persons with Disabilities of the United Nations (UNO) ${ }^{4}$, ratified by the equivalent of a constitutional amendment. In turn, the National Health Policy for People with Disabilities proposes, among other guidelines, the need for the training of human resources and points out the availability of trained health professionals to develop the resulting actions as a priority. Also according to these guidelines, the education and training programs for these professionals must be promoted by different institutions involved with the issue, at the federal, state and municipal levels, including the engagement of nonstate public institutions. Additionally, integrated actions by the Ministry of Education and higher education institutions must be promoted, considering the need to incorporate contents and disciplines that address rehabilitation and health care for people with disabilities (PWD) in the undergraduate curricula of the health area ${ }^{5}$.

The partnership between the Ministries of Health and Education seeks to disseminate, together with educational institutions and the school community, information related to disabilities, prevention and limitation of deficiencies aiming to contribute to the quality of life of this specific population. This refers to the need to adapt the curricula of undergraduate courses in the health area to include content related to the health of PWD, as well as the development of methodologies and didactic-pedagogical materials, aiming to comply with the guidelines established in the National Health Policy of People with Disabilities ${ }^{5}$.

Brazil has advanced regarding the implementation of the necessary support for the full and effective exercise of the protagonism and legal capacity by all PWD. However, for the prerogatives of the UNO Convention to truly occur in these people's lives, a broad articulation of government policies for access to education, social inclusion, health care and promotion of accessibility must be implemented. The training of health professionals cannot be dissociated from this social articulation and needs to meet their specific demands. Therefore, the perspective of comprehensiveness in health care for people with disabilities, in addition to assistance that is specific to their condition, should also include assistance for comorbidities and injuries potentiated by the most diverse social determinants of the health-disease process.

Have the theoretical assumptions related to health care for people with disabilities expressed in the National Curriculum Guidelines for undergraduate medical courses ${ }^{6}$ become a reality in Brazilian medical schools? This is the question that inspired this investigation, whose objective was to identify the presence of aspects related to health care for people with disabilities in the curricula of undergraduate medical courses in Brazil.

\section{METHOD}

This was a descriptive study, whose methodological trajectory involved the documental analysis of pedagogical projects of Medicine courses offered by Higher Education Institutions in Brazil, in addition to syllabuses and programmatic contents of the disciplines and modules, aiming to identify whether these institutional documents express aspects related to health needs of people with disabilities.

The theoretical references used for the analysis of the research data was the normative established by the National Curriculum Guidelines for Undergraduate Courses in Medicine $(\mathrm{NCG})^{6}$, according to Resolution N. 3, of June 20, 2014, of the Chamber of Higher Education of the National Council of Education/Ministry of Education, which establishes the need to include health care for people with disabilities in the training of physicians in Brazil. The inclusion criteria comprised the medical courses listed in the e-MEC Registry of Higher Education Institutions and Courses ${ }^{7}$, official and single database containing information on Higher Education Institutions - HEls and undergraduate courses of the Federal Education System, until November 30, 2018. The data from the e-MEC Registry are in accordance with the authorizing acts of higher education institutions and courses, edited based on the competent regulatory processes, according to the Normative Ordinance issued by MEC, N. 40/2007.

In addition to the registration in the e-MEC Registry, another inclusion criterion considered was the availability of the pedagogical projects of the courses (PPC), syllabuses and programmatic contents of disciplines and modules found on the public websites of the Higher Education Institutions. Courses of which institutions did not make these documents available for public access were excluded from the sample. Based on this official information, detailed information about the several courses was sought, through a search carried out on the websites available on the internet, using a previously defined research form.

Once the set of documents for the study was established, an analysis process was carried out, which included three 
stages: (I) pre-analysis; (II) analysis; (III) classification. During the pre-analysis, a computerized search was carried out for the terms present in the official documents of the courses and that referred to the health of PWD. The following keywords were used as search indicators: "person with disability", "PWD", "disability", 'disabled", "physically disabled", "paraplegic", "paraplegia", "tetraplegic", "tetraplegia", "intellectual disability", "intellectually disabled", "cognitive deficit", "mental retardation", "cerebral palsy", "autism", "autistic", "visual impairment", "blind", "blindness", "hearing impairment", "deaf", "deafness", "mute", "muteness", "deaf-mute", "aphasic", "aphasia", "Libras", "person with special needs", "accessibility", "clinical skills", "assistance", "assisting", "anamnesis", "clinical interview", "exam", "physical examination", "clinical examination", "inspection", "palpation", "palpate", "percussion", "auscultation". This phase of computerized search for terms was complemented by a detailed reading of paragraphs and sections in which the use of keywords referred to the health of PWD. This first, less systematic reading allowed the initial familiarization with the documents and, at the same time, the recognition and identification of the registration units, that is, the excerpts that conveyed contents related to the health care of PWD, as well as the description of the development of clinical skills such as, for instance, performing the anamnesis and physical examination.
Phases II and III of the analysis of the material itself were carried out concomitantly and allowed the classification of medical schools by the search for characteristics shared by the registration units, either through semantic criteria (i.e., search for the presence of the same meaning in a given context) and/or syntactic (such as the shared presence of precise linguistic signs). At this point in the analysis, the documents were examined in full, identifying the registration units and transcribing into a table both these units and the context units that corresponded to broader excerpts of the text in which the registration units were contained. Based on the context units, it was possible to analyze more precisely the meaning attributed to the term or concept of interest used in each registration unit.

Based on the theoretical framework of the $\mathrm{NCG}^{6}$ for medical schools, two classes of medical courses were defined, namely: Class I - minimum attendance of the course to the recommendations on care for PWD and Class II - Inclusion in the syllabus and programmatic contents of the curricular components of activities aimed at the development of clinical competences specifically related to the health care of PWD. Chart 1 shows the details of the criteria and references for the construction of these classes, based on the context of how the researched topic emerged in the official documents of the medical courses.

Chart 1. Description of the analysis classification, using the National Curriculum Guidelines as reference for Undergraduate Medical Courses ${ }^{6}$.

Class I - Minimum attendance of the pedagogical project to the recommendations on care for people with disabilities (PWD)

Criterion used: Courses of which registration units fit the recommendations of the NCG related to the "inclusion of the topic of diversity in medical education aiming to promoting equity in health"; strict transcription in the pedagogical project of the text recommended by the NCG.

References in the NCG6: Chapter I (Guidelines), section I (of Health (are): the undergraduate student will be trained to always consider the dimensions of biological diversity (...) and other aspects that comprise the spectrum of human diversity (...) aiming to achieve, among other aspects, the promotion of equity during the adequate and efficient care of people with disabilities (...).

Chapter III, Art. 23 (Of the curricular contents and the pedagogical project of the course): the fundamental contents (...) must be related to the entire health-disease process of the citizen, family and community (...) providing the integrality of health care actions, contemplating: (...) cross-sectional topics in the curriculum that involve knowledge, experiences and systematized reflections about human rights and people with disabilities (item VII).

Class II - Inclusion in the syllabuses and programmatic contents of the curricular components of activities aimed at the development of clinical skills specifically related to the health care of people with disabilities (PCD)

Criterion used: Courses of which units of analysis expand the criteria described for class I, with reference to the development of clinical competences specifically related to health care for people with disabilities, including communication, clinical examination and ethical aspects; includes the description in the syllabuses and programmatic contents of the curricular components of clinical skills and patient care.
Reference in NCG6${ }^{6}$ : Chapter II (of Areas of Competence in Medical Practice), Subsection I (Attention to Individual Health Needs), Article 12: ethical, respectful posture and technical skill in the inspection, palpation, auscultation and percussion, with precision in the use of maneuvers and general and specific physical examination procedures, considering the clinical history, ethnic-racial, gender, sexual orientation, linguisticcultural diversity and of people with disabilities. 
The present study used only secondary data available in documents of public access, without identifying the subjects, in this case, the medical courses in Brazil, in accordance with the ethical principles established by CNS Resolution N. 196, of October 10,1996 , of the National Health Council/Ministry of Health.

\section{RESULTS}

Of the total of 328 medical courses (42\% public and 58\% private) included in the e-MEC Registry of Higher Education Institutions and Courses ${ }^{7}$, the documents of 171 (52.1\%) were available for adequate analysis, including the pedagogical projects of the courses, curricula, syllabuses and programmatic components of the disciplines or modules, and were, therefore, included in the study.

Of the courses included in the study, 89 (52\%) included aspects related to the care of PWD in the publicized documents and 50 (29.2\%) included the teaching of the Brazilian Sign Language (Libras, Língua Brasileira de Sinais), which was the only reference related to PWD found in these documents in 18 (10.5\%) of them. Inclusion was more prevalent in public courses $(n=56 ; 62.9 \%)$ than in private courses $(n=33 ; 37.1 \%)$. Among the courses that included aspects related to the care of PWD in their curricula, $63(70.8 \%)$ were implemented after the NCG were established, that is, as of 2014. The distribution of these courses by region of the country is shown in the Table 1 .

Figure 1 shows that the absolute majority of courses that included aspects related to the care of PWD in their curricula (80; $89.9 \%$ ) did so predominantly focused on Class I, and, more specifically, reproducing the textual content in their official documents found in the NCG. The lack of description of procedural strategies to promote the development of clinical competences related to the care of PWD became evident, in this study called

Table 1. Distribution of medical courses, public and private, which included aspects related to the care of people with disabilities in their curricula, according to the major regions of Brazil.

\begin{tabular}{cccc}
\hline Region & Public & Private & Total \\
\hline North & $05(5.6 \%)$ & $06(6.7 \%)$ & $11(12.4 \%)$ \\
Northeast & $21(23.6 \%)$ & $04(4.5 \%)$ & $25(28.1 \%)$ \\
Midwest & $06(6.7 \%)$ & $03(3.4 \%)$ & $9(10.1 \%)$ \\
Southeast & $15(16.9 \%)$ & $15(16.9 \%)$ & $30(33.7 \%)$ \\
South & $09(10.1 \%)$ & $05(5.6 \%)$ & $14(15.7 \%)$ \\
\hline Total & $56(62.9 \%)$ & $33(37.1 \%)$ & $89(100.0 \%)$ \\
\hline
\end{tabular}

Figure 1. Distribution of medical courses that included aspects related to the care of people with disabilities in their curricula, according to the classification adopted in the study.

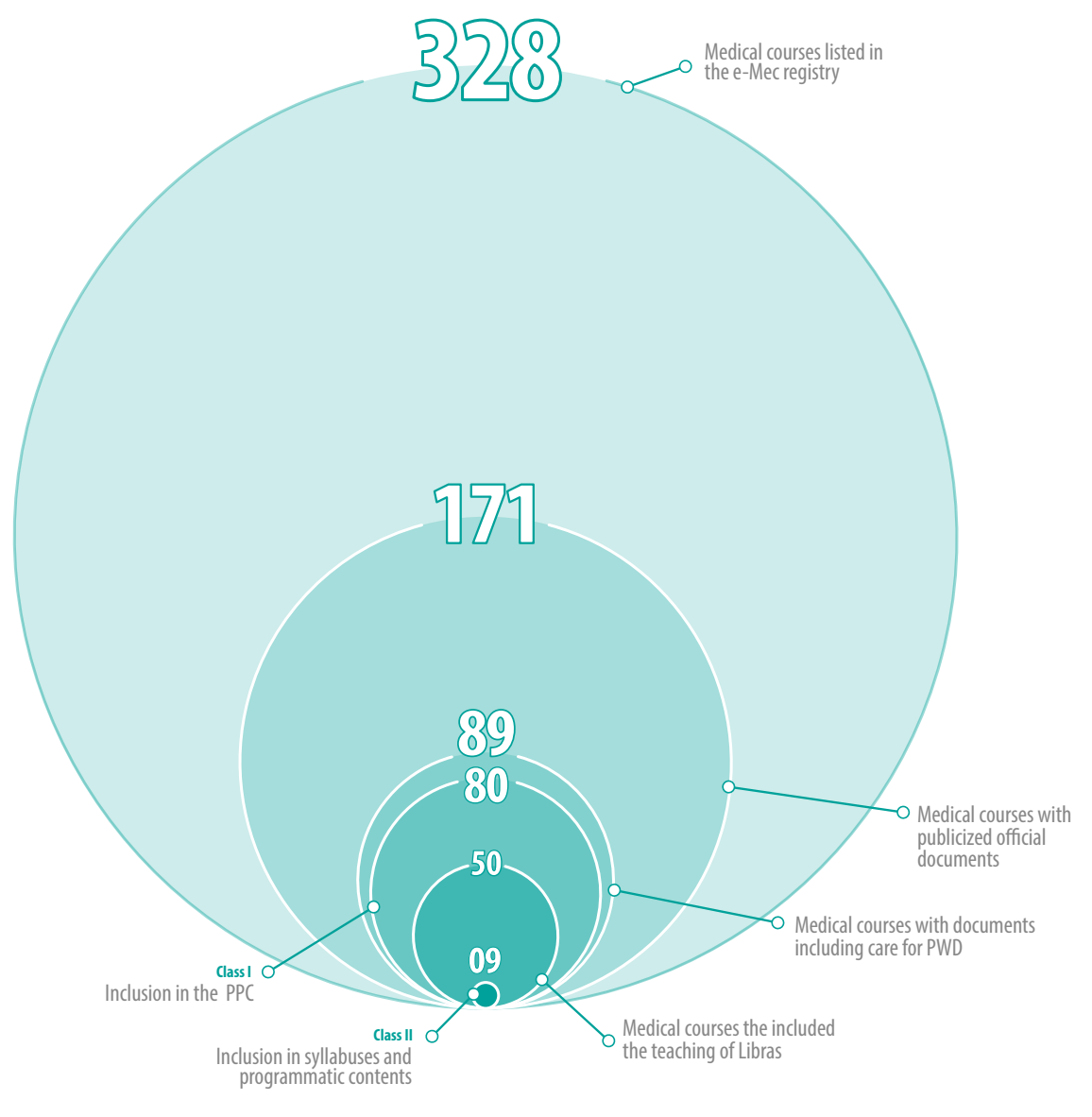


Class II, including communication, clinical examination and ethical aspects. Of the nine courses whose curricula were classified as Class II, eight were public and eight were implemented after the publication of the current NCG. These references were limited to the transcription of textual fragments of Article 12, Subsection II, Subheading " $c$ " of the NCG, namely:

"ethical, respectful posture and technical skill in the inspection, palpation, auscultation and percussion, with precision in the use of maneuvers and procedures of general and specific physical examination, considering the clinical history, ethnic-racial, gender, sexual orientation, linguistic-cultural diversity and of people with disabilities."

Table 2 shows the distribution of medical courses that included aspects related to the care of PWD in their curricula, according to the analysis classes, Classes I and II; type of funding, whether public or private; and according to the establishment after the implementation of the current NCG, that is, whether before or after 2014.

\section{DISCUSSION}

Medical students report feeling uncomfortable when interacting with PWD and medical students, residents and practicing physicians have shown deficiencies regarding their practical knowledge of even the most common forms of disability ${ }^{9}$.

The main issue to be discussed by Brazilian medical schools is how to implement comprehensive health care for people with disabilities in Brazil, when the development of clinical competences for the exercise of this care has not been encouraged during the training of Brazilian physicians. The results observed in the present study disclose this reality when they verify that PWD are not mentioned in the curricula of $48 \%$ (82) of the 171 courses whose official documents were available for public consultation. No less a matter of concern is the finding that the other $52 \%$ (89) of these courses, in almost their entirety, are limited to the transcription of textual fragments of the NCG related to the health care of PWD, with only $10.1 \%$ (9) of these 89 courses, somehow including aspects related to anamnesis, physical examination or ethical aspects of health care for people with disabilities in their curricular components. Both findings represent challenges to be overcome by medical training in the country, as the importance currently given to the health of PWD by Brazilian medical schools does not seem to be able to guarantee the experience of training skills that allow, or at least encourage, medical students towards the health care of PWD.

Currently, this is an important challenge for all medical schools worldwide. In the United States, PWD represent $22.2 \%$ of the population and it is estimated that all physicians attend PWD in their clinical practice. On the other hand, studies show that PWD are inadequately attended by the health system, with the limited training of health professionals when caring for PWD being pointed out as one of the probable causes. In this sense, Ankam et al. highlight the need to introduce learning objectives specifically related to the health of PWD into the curricula, aiming to train future physicians to provide adequate care to this population ${ }^{10}$.

Medical schools represent spaces of great importance for the production of knowledge in health and an equivalent importance should be attributed to these powerful professional training spaces as catalysts for the implementation of public health policies. In Brazil, there is an explicit constitutional guarantee that grants the Unified Health System (SUS, Sistema Único de Saúde) the competence to, among other attributions, order the training of human resources in the health area ${ }^{11}$. In the context of health care for PWD, the articulation between medical schools and SUS takes on a very special dimension given the pressing need to implement the National Health Policy for People with Disabilities, the National Plan for the Rights of Persons with Disabilities - Plano Viver sem Limite and the strengthening of the Care Network for People with Disabilities.

Ciuffo et al. ${ }^{11}$ reinforce that recognizing SUS as the organizer of training requires a profound restructuring of

Table 2. Distribution of medical courses that included aspects related to the care of people with disabilities in their curricula, according to analysis classes, type of funding (public or private) and period when it was established.

\begin{tabular}{ccccc}
\hline & Public & Private & Established before 2014 & Established after 2014 \\
\hline $\begin{array}{c}\text { Class I } \\
\text { Subtotal = } 80(89,9 \%)\end{array}$ & $48(60 \%)$ & $32(40 \%)$ & $25(31.2 \%)$ & $55(68.8 \%)$ \\
$\begin{array}{c}\text { Class II } \\
\text { Subtotal = 09 }(10,1 \%)\end{array}$ & $8(88.9 \%)$ & $1(11.1 \%)$ & $1(11.1 \%)$ & $8(88.9 \%)$ \\
\hline Total = 89 (100\%) & $56(62.9 \%) a$ & $33(37.1 \%) a$ & $26(29.2 \%) a$ & $63(70.8 \%) a$ \\
\hline
\end{tabular}

Class I - Minimum attendance of the course pedagogical project to recommendations on care for people with disabilities; Class II - Inclusion in the syllabuses and programmatic contents of curricular components of activities aimed at the development of clinical skills specifically related to the health care of people with disabilities.

a Percentages expressed in relation to the total of courses $(89 / 100 \%)$. 
medical curricula, specifically, to be carried out through successive and permanent curricular innovations, guided by the principle of integrality - a complex idea that articulates conceptions and practices in health - and by reviewing the health work and management process. For this purpose, it is necessary to break the biomedical paradigm, which still supports health practices and a large part of the medical curricula in Brazil; and the simplistic conception that "being healthy is not having a disease", which implies removing the focus from welfare actions and understanding that care, and no longer assistance, should combine actions for disease prevention, health promotion, in addition to healing and rehabilitation - all requiring a plurality of knowledge -as well as interdisciplinary and multidisciplinary teamwork, preferably in a network. The authors emphasize that many schools still reflect and reproduce the fragmented logic inherent in scientism, failing to enhance what is greatest in the field of education: the possible relationships that can be developed between teachers and students, which will later revert to the relationships established between the professionals and their patients, or between caregivers and those receiving care. A portrait, albeit a partial one, of the disregard for the area of interpersonal relationships has been demonstrated, among other results, by the low rates of effectiveness of SUS, the dissatisfaction of users and many service professionals and in the use of high-cost procedures, very often unnecessary ones ${ }^{11}$.

Reports by PWD portray a reality far from the recommended comprehensive care. Harrington et al. ${ }^{12}$ point out that many primary care services in the United States are not structured to fully meet the demands of people with disabilities regarding physical accessibility, communication and even attitudes. The authors identify more physician barriers than physical barriers in the services and verify that people with disabilities are more sensitive to attitude than physical barriers. Only $2.67 \%$ of the assessed subjects reported difficulties in accessing the medical office, but $36.4 \%$ reported that they had to teach the physician about their disability, leaving the medical appointment feeling that their needs were not fully met.

There is a lack of clarification to family members about the possibilities of development for PWD and ways to overcome the encountered difficulties, or advice for early stimulation. The physicians are unaware of the peculiarities that differentiate a body with from another without disability, which makes it difficult to reduce the risk of avoidable health problems or inadequate procedures, which can even lead to the patient's death, such as autonomic hyperreflexia - a frequent complication in quadriplegic individuals. It is rare for PWD to find physicians with technical skills combined with openness to negotiation regarding health care and who are concerned with issues related to the service, such as reducing the time and energy spent by PWD to receive medical care. For this reason, the PWD end up having to choose which of these skills they consider a priority, at that moment, to the detriment of others ${ }^{13}$.

In gynecology and obstetrics, as an example of one of the priority areas of medical education as a mandatory curricular internship, the perspective of the health of women with disabilities has been shown as deserving major changes to guarantee effective care. Increasingly more women with spinal cord injuries choose to become pregnant, requiring professionals to be prepared to monitor a pregnancy with risk of thrombosis, recurrent urinary tract infection and pressure ulcers, as the pregnant woman gains weight and has autonomic hyperreflexia ${ }^{13}$. Nicolau et al. ${ }^{14,15}$ emphasize that women with disabilities receive insufficient care in primary health care services, which, although historically favor the female clientele, fail to recognize the aspects related to sexual and reproductive rights and the double vulnerability presented by these women, for being female and PWD. Some women face prejudice to experience their sexuality and motherhood, as they inhabit a body that clashes with the current aesthetic standards and face society's disbelief that they can meet the gender expectations, such as taking on the roles of caregiver, wife and mother ${ }^{15}$.

Gomes et al. ${ }^{16}$, in an observational, cross-sectional descriptive study, interviewed 101 physicians from 24 different specialties and asked whether the physician had ever treated a deaf patient, whether the patient was accompanied by someone, what feeling was perceived in relation to the consultation (occurred or potential), if the physician knew Libras and whether they saw the knowledge of Libras as important in their medical practice. In this sample, $92.1 \%$ of the interviewed physicians declared they had already treated deaf patients and $76.2 \%$ considered the knowledge of Libras important for their medical practice. Despite the significant proportion, only one physician out of the 101 interviewees declared to have basic knowledge of Libras and the predominant feelings among the interviewed physicians were uncertainty and discomfort during the consultation ${ }^{16}$.

Communication barriers represent a real obstacle to the service effectiveness, the creation of bonds and the success of treatment guidelines, compromising the user's safety. Regarding the care of deaf individuals, these barriers represent an even more harmful potential and must be overcome as a sociocultural problem. According to IBGE data collected in 2010, of the $45,606,048$ people in Brazil with some type of disability, $7.6 \%$ of them are totally deaf, that is, $1.2 \%$ of the Brazilian population ${ }^{2}$. In the present study, the inclusion of Libras as a curricular component, regardless of whether it is mandatory or optional, was observed in less than one third $(n=50 ; 29.2 \%)$ of 
the courses whose curricula were available for evaluation, being the only reference to care for the health of PWD in 18 (10.5\%) of them. Libras is a linguistic system as complex as the spoken language and is an important tool for health professionals in the field of diagnosis and effective treatment, being directly related to good patient care. The perception that the deaf patient deserves access and treatment like any other citizen is reflected in the several legislative measures, such as Federal Law N. 10,436/02, which provides the guarantee of adequate care and treatment for people with hearing impairment by public institutions and public service providers in the health area; Law N. $10.098 / 00$ or the Accessibility Law, which implements the training of professional interpreters in article 18; and Decree N. 5626/05, which regulates that at least $5 \%$ of the employees in a health unit must know Libras. However, despite being covered by legislation, assistance to the deaf individual is precarious. Adequate communication and understanding between deaf and normal-hearing individuals are key factors for inclusion, which can hardly happen with so few normalhearing individuals who know Libras. Although the teaching of Libras has been offered as an elective subject in most courses at higher education institutions for the last ten years, we see little manifestation of this knowledge among health professionals ${ }^{16}$.

The actual inclusion of people with disabilities in medical education must take place in the different disciplines throughout the course, including those in the clinical and surgical areas. Discussing issues related to disability in an elective discipline or at a single point during the course can be a first step, but it should not be the only one. Prenatal care and childbirth for pregnant women with disabilities, for instance, should be taught during the discipline of Obstetrics; in Semiology classes, students must learn how to communicate with people who are deaf or speech impaired, or how to recognize a disease based on signs and symptoms that show a different presentation in people with spinal cord injury. Moreover, it is important that the inclusion of health care for people with disabilities be planned according to a rationality and that teachers/doctors have their practice guided by the biopsychosocial model of perceiving the disability. Finally, direct contact with people with disabilities in the role of educators is crucial, participating in conversations, as lecturers or standardized patients ${ }^{17}$. Medical students' exposure to a longitudinal curriculum to care for people with disabilities has led to a significant improvement in several factors related to comfort and attitudes 9 .

Bosques et al. ${ }^{18}$ carried out an intervention study involving the offer of an elective course to $3^{\text {rd }}$ or $4^{\text {th }}$-year medical students, in which they had the opportunity to provide care to patients with neurological and musculoskeletal disorders and to participate in rehabilitation sessions. In addition to the traditional pedagogical methods, the course included studentcentered methodologies, highlighting a practical experience in wheelchair handling. The results showed a significant gain in knowledge about the health-related terminology of PWD, when comparing the pre- and post-intervention periods. Additionally, the medical students had a cognitive gain on the related legislation and resources that can be used when caring for PWD, aiming at reducing barriers to adequate care. As a conclusion of this study, it is suggested that the longitudinal inclusion of topics related to the health of PWD in medical curricula is important to fill the current gaps regarding the access to healthcare for PWD.

To implement comprehensive health care for people with disabilities in the health system, it is necessary for health education to break the paradigm of the health concept of people with disabilities as being centered on disability as a disease; in which the person with a disability is always seen by the health professional as someone who is ill; for the conception of disability as a difference, and the person with disability being someone who has more or fewer limitations depending on the level of architectural/urban, communicational, instrumental, methodological, programmatic or attitudinal accessibility ${ }^{19}$. Many PWD, particularly when their health situation is congenital or long-term, do not necessarily perceive their disability as a problem or a pathology. Having a disability is not incompatible with being healthy and it should not be assumed that the consultation complaint is always related to the disability ${ }^{20}$. For this evolution towards comprehensive care to occur, health professionals need to perceive the person beyond the disability and differentiate disease from disability, avoiding medicalizing disability, that is, declaring as the object of treatment a variation that does not cause functional harm, such as use of growth hormone to 'treat' very short stature in children who do not have any underlying pathology ${ }^{21}$.

Another fundamental aspect for medical training to effectively contribute to the reduction of health inequities faced by PWD is the integration between the health care network and medical schools, aiming to enable practice scenarios capable of guaranteeing experiences that catalyze the teaching-learning process in this specific dimension of care. Without having experienced or practiced health care for PWD during their training, it becomes much more difficult for physicians to be effective in this type of care when practicing their profession. Such experiences should provide opportunities for the association of theoretical and scientific knowledge with the reality of life of a PWD, emphasizing the concrete experiences of these subjects as significant learning situations. Likewise, the curricula, disciplines and teachers must contemplate the health care of PWD beyond the inclusion of the theoretical content, 
prioritizing dynamic pedagogical practices that integrate students with PWD and recognize both as active subjects and protagonists of the teaching-learning process.

Our study has some potential limitations. The technique used for data collection, which involved researching public documents available on the websites of higher education institutions, may have underestimated the number of medical courses that include aspects related to the health of PWD in their curricula. This can be especially important when considering that a significant number of Brazilian medical schools still do not adopt the philosophy of making pedagogical projects of courses, syllabuses and programmatic contents available for public access. On the other hand, the need to meet regulatory criteria has certainly influenced the observed finding that many courses simply transcribe the NCG recommendations into their official documents. Therefore, the study does not allow inferring that students in these courses effectively experience training experiences for the care of PWD. Finally, a research based on document analysis is not able to assess the students'knowledge, skills and attitudes; therefore, it is worth emphasizing that the study was designed to identify the visibility of the topic in medical courses in Brazil. Further investigations are required to assess the effectiveness of the didactic-pedagogical strategies aiming to develop clinical skills in health care for PWD.

\section{FINAL CONSIDERATIONS}

In the curricula of Brazilian medical courses, the inclusion of educational strategies specifically aimed at the health care of PWD is still incipient as a mechanism to promote the training of health professionals, as required by the National Health Policy for People with Disabilities. In Brazil, the data obtained from institutional documents available on the public websites of Higher Education Institutions that offer medical courses indicate a dramatic situation regarding the invisibility of issues related to PWD in medical training and the need for the development and implementation of educational strategies specifically aimed at care for PWD in medical curricula. The study reinforces the essential role of competent health care for PWD as a strategy to mitigate the health inequities faced by this population.

\section{ACKNOWLEDGMENTS}

To the Ministry of Education of Brazil and Instituto Santos Dumont for their financial and institutional support. To Fernando de Souza Silva for the graphic design of the illustration about the observed results.

\section{AUTHORS' CONTRIBUTION}

Reginaldo Antônio de Oliveira Freitas Júnior: study concept and design, analysis and interpretation of data; writing of the manuscript, critical review of the intellectual content and final approval of the version to be published. Rafael Antônio Santana de Oliveira Freitas: Data collection, development of document analysis tools, data analysis and interpretation; writing of the manuscript and final approval of the version to be published. Marcelo Pacheco Carvalho: Coordination of the data collection process and development of document analysis tools, data collection, data interpretation; writing of the manuscript and final approval of the version to be published. Samantha Santos de Albuquerque Maranhão: Writing of the manuscript, critical review of the intellectual content and final approval of the version to be published. Lilian Lira Lisboa: Writing of the manuscript, critical review of the intellectual content and final approval of the version to be published. George Dantas de Azevedo: study concept and design, analysis and interpretation of data; writing of the manuscript, critical review of the intellectual content and final approval of the version to be published.

\section{CONFLICTS OF INTEREST}

The authors declare no conflicts of interest.

\section{SOURCES OF FUNDING}

The authors declare no sources of funding.

\section{REFERENCES}

1. World Health Organization. World report on disability. Geneva:WHO; 2011 [access in 20 may 2019]. Available from: https://www.who.int/disabilities/ world_report/2011/report.pdf.

2. Instituto Brasileiro de Geografia e Estatística. Censo demográfico 2010. Características gerais da população, religião e pessoas com deficiência. Rio de Janeiro: IBGE; 2010 [access in 20 may 2019]. Available from: https:// biblioteca.ibge.gov.br/visualizacao/periodicos/94/cd_2010_religiao_ deficiencia.pdf.

3. Brasil. Plano Nacional dos Direitos da Pessoa com Deficiência - Viver sem Limite. Brasília: Secretaria Nacional de Promoção dos Direitos da Pessoa com Deficiência; 2013.

4. Organização das Nações Unidas. Convenção Internacional sobre os Direitos das Pessoas com Deficiência e seu Protocolo Facultativo. Nova York: ONU; 2007.

5. Brasil. Portaria $n^{\circ} 1.060$, de 5 de junho de 2002. Art. $1^{\circ}$ Aprovar, na forma do Anexo desta Portaria, a Política Nacional de Saúde da Pessoa Portadora de Deficiência. Diário Oficial da República Federativa do Brasil; 2002. Seção 1, p. 21.

6. Brasil. Resolução CNE/CES n 3, de 20 de junho de 2014. Institui Diretrizes Curriculares Nacionais do Curso de Graduação em Medicina e dá outras providências. Diário Oficial da República Federativa do Brasil; 2014.

7. Brasil. Portaria Normativa $n^{\circ} 21$, de 21 de dezembro de 2017. Dispõe sobre o sistema e-MEC, sistema eletrônico de fluxo de trabalho e gerenciamento de informações relativas aos processos de regulação, avaliação e supervisão da educação no sistema federal de educação, e o Cadastro Nacional de Cursos e Instituições de Educação Superior - Cadastro e-MEC. Brasília: Ministério da Educação; 2017. 
8. Brasil. Portaria Normativa MEC no 40/2007. Institui o e-MEC, sistema eletrônico de fluxo de trabalho e gerenciamento de informações relativas aos processos de regulação, avaliação e supervisão da educação superior no sistema federal de educação, e o Cadastro e-MEC de Instituições e Cursos Superiores e consolida disposições sobre indicadores de qualidade, banco de avaliadores (Basis) e o Exame Nacional de Desempenho de Estudantes (ENADE) e outras disposições. Brasília: Ministério da Educação; 2007.

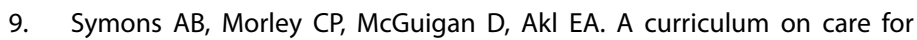
people with disabilities: effects on medical student self-reported attitudes and comfort level. Disabil Health J. 2014 Jan;7(1):95-88.

10. Ankam NS, Bosques $G$, Sauter $C$, Stiens $S$, Therattil M, Williams FH, et al. Competency-based curriculum development to meet the needs of people with disabilities: a call to action. Acad Med. 2019 June;94(6):781-8.

11. Ciuffo RS, Ribeiro VMB. Sistema Único de Saúde e a formação dos médicos: um diálogo possível? Interface Comun Saúde Educ. 2008;12(24):125-40.

12. Harrington AL, Hirst MA, Hammond FM, Norton HJ, Bocknek MD. Assessment of primary care services and perceived barriers to care in persons with disabilities. Am J Phys Med Rehabil. 2009;88(10):852-63.

13. Costa LSM. Educação médica e atenção integral à saúde da pessoa com deficiência. Rev Bras Educ Med. 2011;35(3):302-1.

14. Nicolau SM. Deficiência, gênero e práticas de saúde: estudo sobre a integralidade em atenção primária [tese]. São Paulo: Universidade de São Paulo; 2011.
15. Nicolau SM, Schraiber LB, Ayres JRCM. Mulheres com deficiência e sua dupla vulnerabilidade: contribuições para a construção da integralidade em saúde. Cien Saude Colet. 2013;18(3):872-63.

16. Gomes LF, Machado FC, Lopes MM, Oliveira RS, Medeiros-Holanda B, Silva LB, et al. Conhecimento de Libras pelos médicos do Distrito Federal e atendimento ao paciente surdo. Rev Bras Educ Med. 2017;41(3):390-6.

17. Costa LSM, Koifman L. O ensino sobre deficiência a estudantes de medicina: o que existe no mundo? Rev Bras Educ Med. 2016;40(1):58-3.

18. Bosques G, Philip K, Francisco GE. Integration of chronic disability management in a medical student curriculum. Am J Phys Med Rehabil. 2021 Feb;100(2S Suppl 1):S30-S33.

19. Costa LSM. Inclusão no curso médico: atenção integral à saúde das pessoas com deficiência. Rio de Janeiro: HP Comunicação; 2015.

20. Shakespeare T, lezzoni LI, Groce NE. Disability and the training of health professionals. The Lancet. 2009 Nov;374(9704):1815-6.

21. Couser GT. What disability studies has to offer Medical Education. J Med Humanit. 2010 Nov;32(1):21-30. 